\title{
Kualitas Embrio pada Sapi Simmental dan Limousin dengan Kadar Protein Pakan Berbeda
}

The Embryo Quality on Simmental and Limousin Cattle with Different Feed Protein Levels

\author{
D. Hardiyanto ${ }^{1}$, C. Sumantri ${ }^{2}$, D. Zamanti ${ }^{3}$ \\ ${ }^{1}$ Mahasiswa Departemen Ilmu Produksi dan Teknologi Peternakan, Fakultas Peternakan, Institut Pertanian \\ Bogor \\ ${ }^{2}$ Staff Pengajar Departemen Ilmu Produksi dan Teknologi Peternakan, Fakultas Peternakan, Institut Pertanian \\ Bogor \\ ${ }^{3}$ Staff Bagian Penata, Balai Embrio Ternak Cipelang Bogor, Kementrian Pertanian \\ Jln. Agatis Kampus IPB Dramaga, Bogor 16680 \\ Correspondence author : dany.hardiyanto@live.com
}

\begin{abstract}
Enhancement beef population could be conducted using the MOET (multiple ovulation, the embryo transfer). This method is done to ensure the quality of embryos have high production. Determination of embryo quality on this method gave fed with $15 \%-20 \%$ protein levels. This research was aim to evaluate influenced of different gave fed againt different breed. The evaluation was done by observing at the influence of the environment against the production of embryos. The assessment was conducted using factorial design experiment. The evaluation results showed average production of embryos in different breeds was not significant $(\mathrm{P}>0.05)$ influence to embryo quality quality. An important factor for obtaining the production of viable embryo transfer were not linked to individual breeds.
\end{abstract}

Key words: feeding, limousin, protein content, embryo quality, simmental.

\section{PENDAHULUAN}

Populasi ternak di Indonesia telah mengalami peningkatan dari tahun ke tahun akan tetapi konsumsi daging oleh masyarakat tidak dapat terpenuhi. Data populasi dan produksi daging di Indonesia pada tahun 2014 sebesar 14.726.880 ekor dan 497.670 ton (DPKH 2015). Hingga saat ini kebutuhan daging tersebut belum dapat memenuhi masyarakat Indonesia. Produksi protein hewani harus dilakukan secara efisien agar dapat terjangkau oleh daya beli masyarakat dan tanpa merugikan peternak. Masalah tersebut dapat diatasi oleh teknologi reproduksi melalui pemanfaatan ternak yang memiliki genetik unggul dengan metode bioteknologi dan manajemen yang baik. Metode bioteknologi yang dapat dimanfaatkan untuk penyebaran dan peningkatan populasi ternak unggul dengan metode superovulasi pada rangkaian program Transfer Embrio (TE).

Terlepas dari teknologi reproduksi, terdapat faktor yang mempengaruhi manipulasi embrio yaitu pakan ternak yang digunakan selama pemeliharaan ternak. Ternak yang mengalami defisiensi nutrisi akan mengalami penurunan efisiensi reproduksi dan gangguan reproduksi pada ternak betina maupun jantan. Menurut Bearden dan Fuquay (2000), kekurangan protein dalam pakan dapat menyebabkan gangguan reproduksi pada ternak seperti birahi yang lemah, kematian embrio, dan kelahiran prematur.
Sapi simmental dan limousin merupakan bangsa Bos taurus yang merupakan tipe sapi pedaging. Umumnya memiliki jumlah folikel yang rendah dibandingkan Bos indicus (Baruselli et al. 2011). Pemberian pakan protein tinggi diharapkan dapat meningkatkan jumlah dan kualitas embrio yang dihasilkan. Program transfer embrio terdapat beberapa tahapan seperti melakukan seleksi sapi donor, dan resipien pada sapi betina, sinkronisasi estrus, superovulasi, inseminasi buatan (IB), panen embrio dan evaluasi embrio serta transfer embrio (Situmorang dan Triwulaningsih 2004). Superovulasi merupakan suatu prosedur untuk memberikan perlakuan pada ternak betina agar terjadi peningkatan jumlah ovulasi. Penelitian ini mengevaluasi pengaruh kadar protein pakan berbeda yang diberikan pada bangsa sapi simmental dan limousin terhadap kualitas embrio yang dihasilkan.

\section{MATERI DAN METODE}

Waktu dan Lokasi Penelitian

Penelitian dilaksanakan pada bulan Januari hingga Maret 2016. Lokasi penelitian di Balai Embrio Ternak Cipelang, Bogor.

\section{Materi Penelitian}

Alat yang digunakan dalam penelitian yaitu cue mate, IB gun, termometer, syringe, botol media flushing, Stilette Cassou Insemination Gun, kateter Foley, Y konektor, tang clamp, glove, bunsen, cawan petri, pinset, pipet pasteur, 
aspirator, straw, dan mikroskop stereo.

Bahan yang digunakan dalam penelitian yaitu pakan (dedak, kopra, molases, pollard, bungkil kelapa sawit, corn gluten feed (CGF), soybean meal (SBM), rumput gajah, rumput raja dan rumput taiwan), gel, aplikator cue mate, hormon FSH, hormon Prostaglandin F2 $\alpha$ (PGF2 $\alpha$ ) semen, tissue culture medium (TCM), lidocaine HCL, alkohol, streptomicin, penicilin, ringer laktat, calf serum, larutan CR1-A, straw IB, straw TE, dan seal powder.

\section{Metode Penelitian}

\section{Pemberian Pakan}

Pemberian pakan di Balai Embrio Ternak Cipelang terhadap sapi donor dan resipien dibagi menjadi 2 yaitu konsentrat dan hijauan. Kosentrat diberikan pada siang hari sedangkan hijauan diberikan pada pagi hari dan siang hari menjelang sore. Hijauan sebelum diberikan kepada ternak terlebih dahulu dilayukan selama 1-2 hari tergantung jenis rumput yang diberikan.

Pencampuran konsentrat dilakukan setiap hari dengan bahan pakan bungkil sawit, kopra, onggok, dedak, CGF, molasses, dan bungkil kedelai. Pemberian konsentrat sebanyak $1 \%$ dan hijauan $10 \%$ dari bobot badan. Konsentrat yang digunakan yaitu dengan kadar protein berbeda $15 \%$ $20 \%$.

\section{Sinkronisasi Birahi dan Superovulasi}

Sinkronisasi estrus dilakukan dengan memasang Controller Internal Drug Release (CIDR) atau lebih dikenal cue mate yang mengandung $60 \mathrm{mg}$ medroxy progesterone acetat dengan aplikasi secara intra vaginal dimulai pada hari ke-0 atau awal mula ternak mengalami estrus hingga hari ke-11. Palpasi rektal dilakukan pada hari ke-7 untuk mengetahui status reproduksi dan kondisi ovarium.

Superovulasi dilakukan dengan memberikan hormon FSH yang disuntikan secara intra muscular (IM) dan dilakukan 2 kali dalam sehari yaitu pagi dan sore. Pemberian hormone FSH dilakukan selama 4 hari dengan dosis menurun ( $4 \mathrm{~mL}, 3 \mathrm{~mL}, 2 \mathrm{~mL}$, dan $1 \mathrm{~mL})$, dimulai pada hari ke- 8 sebanyak 2 kali sehari pada pagi dan sore hari sebanyak $4 \mathrm{~mL}$, hari ke-9 sebanyak $3 \mathrm{~mL}$, hari ke-10 sebanyak $2 \mathrm{~mL}$ dan penambahan prostaglandin F2 $\alpha$ (PGF2 $\alpha$ ), hari ke-11 sebanyak $1 \mathrm{~mL}$ dan dilakukan pencabutan cue mate.

\section{Inseminasi Buatan (IB), Pembilasan (flushing), dan Transfer Embrio (TE)}

Inseminasi buatan (IB) dilakukan pada hari ke-12 dan 13 dengan penyuntikan 2 kali dalam sehari yaitu pagi dan sore. Palpasi rektal dilakukan pada hari ke-7 setelah dilakukan IB untuk mengetahui corpus luteum (CL) pada ovarium kiri dan kanan. Setelah dilakukan palpasi, maka dilakukan pembilasan (flushing) untuk mengoleksi embrio dari sapi donor yang telah diberikan perlakuan superovulasi. Media flushing yang digunakan yaitu larutan ringer laktat bersuhu $37^{\circ} \mathrm{C}$ yang ditambahkan antibiotik (Penicillin $10.000 \mathrm{IU}$ dan streptomycin $100 \mathrm{mg}$ ) dan calf serum $1 \%$.

Persiapan yang dilakukan sebelum dilakukan pembilasan, sapi donor ditenangkan terlebih dahulu dengan penyuntikan secara epidural menggunakan Lidocaine $\mathrm{HCl} 2 \%$, setelah pembilasan selesai maka sapi donor dilakukan penyuntikan kembali dengan $\mathrm{PGF} 2 \alpha$, pemberian antibiotik, dan antiseptik (povidone iodine) 30-50 mL dengan penyuntikan secara uterin. Alur superovulasi dan sinkronisasi birahi dapat dilihat pada Gambar 1.

Alur sinkronisasi yang digunakan untuk sapi resipien menggunakan 2 metode yaitu single dan double PGF2 $\alpha$. Sapi resipien yang telah terseleksi serta siap untuk dilakukan transfer embrio dapat digunakan sebagai tempat berkembangnya embrio menjadi individu baru. Transfer embrio (TE) dilakukan dengan penyuntikan 2 kali dalam sehari yaitu pagi dan sore. Palpasi rektal dilakukan pada hari ke-0 sebelum dilakukan TE untuk mengetahui folikel dan corpus luteum (CL) pada ovarium kiri dan kanan.

Setelah dilakukan palpasi terdapat folikel, maka sapi resipien dilakukan penyuntikan dengan single PGF2 $\alpha$ pada hari ke-2 setelah palpasi rektal yang diharapkan 1-2 hari kemudian sapi mengalami estrus pada hari ke-3 atau ke-4 dan siap dilakukan TE pada hari ke-10 atau ke-11 setelah terjadinya estrus. Akan tetapi bila saat dilakukan palpasi terdapat corpus luteum (CL) maka sapi resipien dilakukan penyuntikan dengan double $\mathrm{PGF} 2 \alpha$ pada hari ke-10 atau ke-11 setelah palpasi rektal pada hari ke- 8 atau ke-9 yang diharapkan pada hari ke-12 atau ke-13 sapi akan mengalami estrus dan siap dilakukan TE pada hari ke-19 atau ke-20 setelah terjadinya estrus. Alur sinkronisasi birahi resipien dapat dilihat pada Gambar 2.

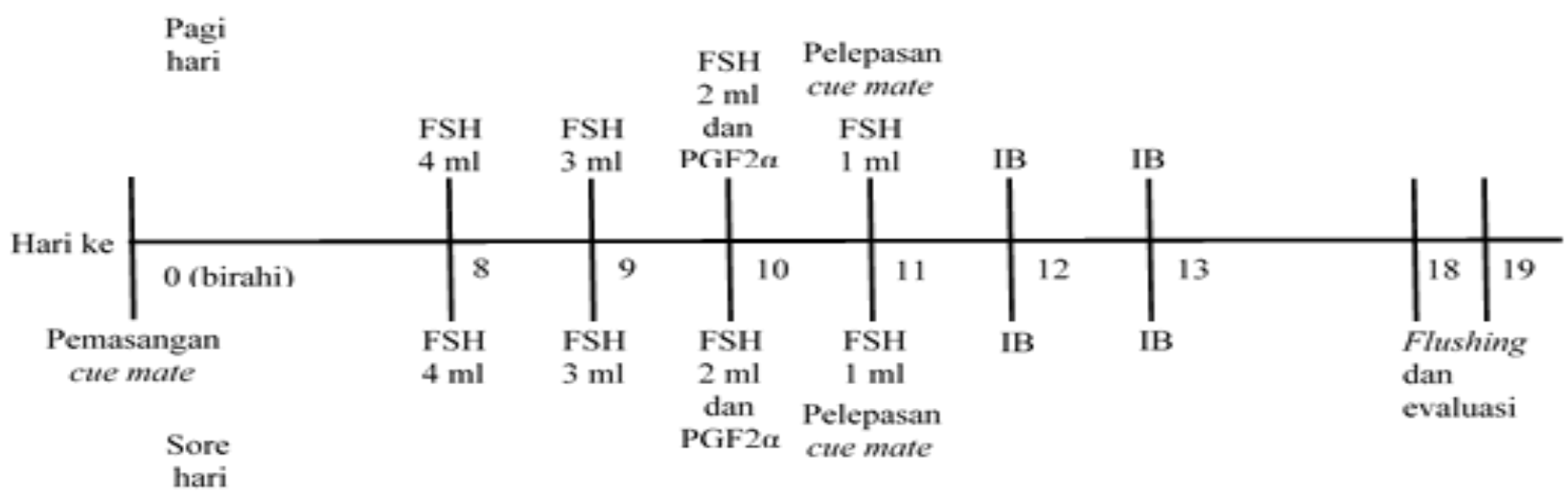

Gambar 1 Alur superovulasi dan sinkronisasi birahi donor 
Folikel

(Single PGF2 $\alpha$ )

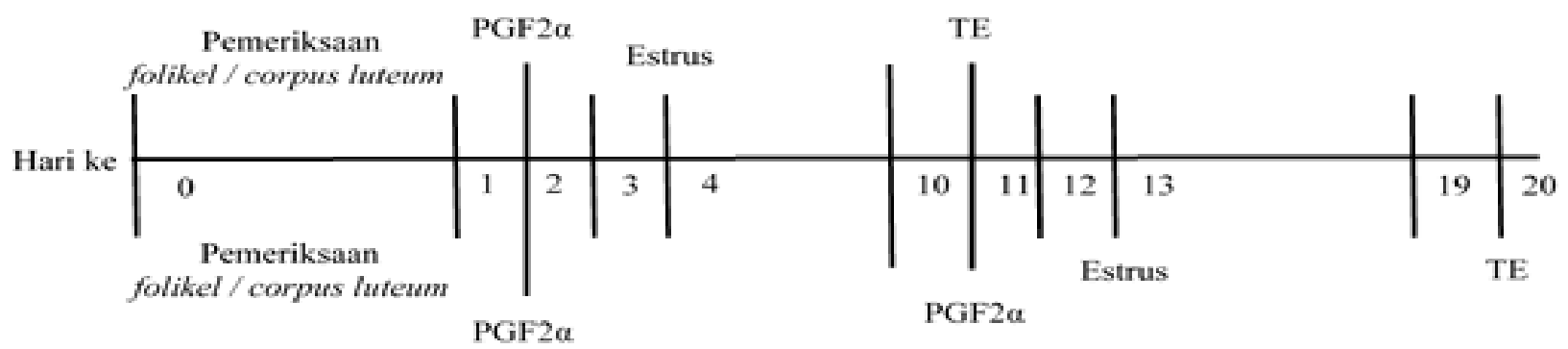

Corpus tureum

(Double PGF2 $\alpha$ )

Gambar 2 Alur sinkronisasi birahi dan transfer embrio resipien

\section{Evaluasi Embrio}

Kegiatan koleksi embrio dilakukan melalui metode pembilasan, maka hasilnya dibawa ke laboratorium untuk dilakukan evaluasi dan klasifikasi embrio. Evaluasi meliputi filtrasi untuk memisahkan embrio dari bendabenda asing, observasi menggunakan media (ringer laktat, calf serum, penicillin, dan streptomicin). Koleksi dilakukan dengan selang dan pipet pasteur serta mikroskop dengan pembesaran 100x untuk melihat tahap perkembangan sel, morfologi, dan kualitas embrio.

\section{Peubah yang Diamati}

1. Jumlah embrio dan ovum terkoleksi yang dilakukan berdasarkan jumlah embrio kualitas 1, 2, 3, DG, dan UF.

2. Presentase jumlah embrio layak transfer (ELT), yaitu jumlah embrio kualitas 1, 2, dan 3 terhadap jumlah total embrio dan ovum terkoleksi.

ELT $=\frac{\sum \text { embrio kualitas } 1,2, \text { dan } 3}{\sum \text { embrio dan ovum terkoleksi }} \times 100 \%$

3. Proporsi jumlah embrio tidak layak transfer (ETLT), yaitu jumlah embrio kualitas DG terhadap jumlah total embrio dan ovum terkoleksi.

$$
\text { ETLT }=\frac{\sum \text { embrio kualitas DG }}{\sum \text { embrio dan ovum terkoleksi }} \times 100 \%
$$

4. Proporsi jumlah sel telur (ovum) yang tidak terbuahi (UF), yaitu jumlah ovum terkoleksi dikurangi jumlah total embrio.

$$
\mathrm{UF}=\sum \text { embrio dan ovum terkoleksi } \cdot \sum \text { embrio } \times 100 \%
$$

\section{Analisis Data}

Perbandingan pengaruh pakan di Balai Embrio Ternak Cipelang dianalisis dengan menggunakan Rancangan Acak Lengkap pola Faktorial untuk mengetahui interaksi dari sapi simmental dan limousin dengan kadar protein pakan berbeda terhadap kualitas embrio dan sel telur yang diperoleh. Menurut Widiharih (2007) rumus dari Rancangan Acak Lengkap Pola Faktorial sebagai berikut:

$$
\mathrm{Y}_{\mathrm{ger}}=\mu+\alpha_{\mathrm{g}}+\beta_{\mathrm{e}}+(\alpha \beta)_{\mathrm{ge}}+\varepsilon_{\mathrm{ger}}
$$

Keterangan:

$\mathrm{Y}_{\text {ger }} \quad$ : Perolehan kualitas embrio

$$
\begin{array}{ll}
\mathrm{M} & \text { : Rataan kualitas embrio } \\
\alpha_{\mathrm{g}} & \text { : Pengaruh bangsa sapi } \\
\beta_{\mathrm{e}} & \text { : Pengaruh kadar protein } \\
(\alpha \beta)_{\mathrm{ge}} & \text { : Pengaruh interaksi } \\
\varepsilon_{\text {ger }} & \text { : Pengaruh galat pengamatan }
\end{array}
$$

\section{HASIL DAN PEMBAHASAN}

\section{Perolehan Embrio dengan Bangsa Sapi dan Kadar Protein Pakan Berbeda}

Hasil perolehan embrio pada bangsa sapi simmental dan limousin umur 3-6 tahun terhadap pemberian kadar protein 15\%-20\% menunjukkan tidak terdapat pengaruh terhadap kualitas embrio yang dihasilkan. Perbandingan proporsi perolehan kualitas embrio dari kedua bangsa dapat dilihat pada Tabel 1.

Pemberian kadar protein berbeda diharapkan dapat terlihat secara jelas pada rataan perolehan embrio layak transfer (ELT) atau terjadinya fertilitas 2 sel yaitu sel jantan dan betina yang paling baik dengan pemberian pakan dengan kadar protein berbeda. Protein dalam pakan akan memberikan pengaruh langsung terhadap kadar protein dalam darah, karena protein dalam pakan akan dicerna dan diubah menjadi protein yang beredar di dalam darah (Kaneko et al. 2008). Menurut McGeady et al. (2006) fertilisasi merupakan proses bertemunya sel sperma dengan sel telur. Sel telur diaktivasi untuk memulai perkembangannya dan inti sel dari 2 gamet akan bersatu untuk menyempurnakan proses reproduksi seksual. Tabel 1 menunjukkan bahwa pada kadar protein pakan 17\% perolehan embrio layak transfer mencapai optimum.

Umumnya semakin bertambah umur sapi, apabila pakan yang diberikan memiliki kualitas yang rendah maka perolehan embrio dapat menurun karena saat sapi berumur muda diharapkan dapat berproduksi secara optimal serta faktor lingkungan pun dapat berpengaruh terhadap individu sapi selama pemeliharaan dan penanganan saat melakukan pengecekan status reproduksi. Menurut $\mathrm{Su}$ et al. (2009), bahwa tingkat tertinggi pembelahan dan blastosis berturutturut terjadi pada sapi muda (kurang dari 7 tahun), sapi tua (7-8 tahun) dan sapi yang lebih tua. Kenaikan umur donor akan menurunkan respon superovulasi dan produksi embrio, hal ini disebabkan adanya penurunan aktivitas reproduksi 
Tabel 1 Proporsi perolehan embrio dan sel telur (ovum) dari bangsa sapi dan kadar protein berbeda

\begin{tabular}{|c|c|c|c|c|c|c|c|}
\hline Bangsa & $\begin{array}{c}\text { Kadar protein } \\
(\%)\end{array}$ & $\begin{array}{l}\text { Jumlah ternak } \\
\text { (n) }\end{array}$ & $\begin{array}{l}\text { Total flushing } \\
\text { (unit) }\end{array}$ & $\begin{array}{l}\text { Total embrio } \\
\text { dan ovum } \\
\text { (flushing }^{-1} \\
\text { ekor }^{-1} \text { ) }\end{array}$ & $\begin{array}{c}\text { Presentase } \\
\text { ELT (flushing } \\
\text { ekor }^{-1} \text { ) }\end{array}$ & $\begin{array}{l}\text { Presentase ETLT } \\
\text { (flushing }^{-1} \text { ekor }^{-1} \text { ) }\end{array}$ & $\begin{array}{c}\text { Presentase } \\
\text { UF (flushing }{ }^{-1} \\
\text { ekor }^{-1} \text { ) }\end{array}$ \\
\hline \multirow[t]{5}{*}{ Simmental } & 15 & 5 & 5 & 53 & 22,64 & 26,42 & 50,94 \\
\hline & 16 & 2 & 2 & 41 & 19,51 & 39,02 & 41,46 \\
\hline & 17 & 6 & 8 & 39 & 66,67 & 15,38 & 17,95 \\
\hline & 18 & 16 & 25 & 245 & 51,84 & 15,10 & 33,06 \\
\hline & 20 & 2 & 2 & 7 & 14,29 & 28,57 & 57,14 \\
\hline \multirow[t]{5}{*}{ Limousin } & 15 & 3 & 3 & 31 & 16,13 & 32,26 & 51,61 \\
\hline & 16 & 5 & 5 & 61 & 29,51 & 32,79 & 37,70 \\
\hline & 17 & 9 & 9 & 108 & 48,15 & 12,04 & 39,81 \\
\hline & 18 & 12 & 17 & 209 & 39,23 & 28,71 & 32,06 \\
\hline & 20 & 4 & 4 & 29 & 68,97 & 17,24 & 13,79 \\
\hline
\end{tabular}

Keterangan: (ELT) embrio layak transfer. (ETLT) embrio tidak layak transfer. (UF) sel telur (ovum) tidak terbuahi. Total embrio dan ovum merupakan jumlah embrio dan sel telur terkoleksi.

Tabel 2 Hasil perolehan Embrio Layak Transfer pada bangsa sapi dan kadar protein berbeda

\begin{tabular}{lcccccc}
\hline Bangsa & $\begin{array}{c}\text { Kadar protein } \\
(\%)\end{array}$ & $\begin{array}{c}\text { Jumlah ternak } \\
\text { (n) }\end{array}$ & $\begin{array}{c}\text { Total flushing } \\
\text { (unit) }\end{array}$ & $\begin{array}{c}\text { Total ELT } \\
\text { (flushing } \text { ekor }^{-1} \text { ) }\end{array}$ & $\begin{array}{c}\text { Rata-rata ELT } \\
\text { (flushing } \text { ekor }^{-1} \text { ) }\end{array}$ & $\begin{array}{c}\text { Kisaran } \\
\text { (flushing } \text { ekor }^{-1} \text { ) }\end{array}$ \\
\hline Simmental & 15 & 5 & 5 & 12 & $2,40 \pm 2,07$ & $0-5$ \\
& 16 & 2 & 2 & 8 & $4,00 \pm 5,66$ & $0-8$ \\
& 17 & 6 & 8 & 26 & $4,33 \pm 5,72$ & $0-14$ \\
& 18 & 16 & 25 & 127 & $7,94 \pm 8,23$ & $0-27$ \\
Limousin & 2 & 2 & 1 & $0,50 \pm 0,71$ & $0-1$ \\
& 15 & 3 & 3 & 5 & $1,67 \pm 2,89$ & $0-5$ \\
& 16 & 5 & 5 & 52 & $3,60 \pm 3,78$ & $0-9$ \\
& 17 & 9 & 9 & 82 & $5,78 \pm 3,73$ & $0-11$ \\
& 18 & 12 & 17 & 20 & $4,82 \pm 7,02$ & $0-25$ \\
\end{tabular}

Keterangan: (ELT) embrio layak transfer. Total ELT merupakan jumlah embrio terkoleksi.

dari hewan tersebut (Muawanah 2000). Menurut Rensis dan Scaramuzzi (2003), tingkat stress dapat pula mempengaruhi jumlah embrio yang dihasilkan oleh bangsa sapi tersebut.

\section{Perolehan Kualitas Embrio Layak Transfer (ELT)}

Hasil perolehan ELT pada kadar protein pakan 17\%-18\% menunjukkan rata-rata hasil ELT yang optimum. Perolehan kualitas embrio ELT dari kedua bangsa dapat dilihat pada Tabel 2. Penggunaan individu sapi yang berumur muda diharapkan dapat terlihat produksi optimum perolehan dan kualitas embrio. Hal tersebut sesuai menurut Puspita (2014) dalam penelitiannya menyatakan, umur sapi donor yang memberikan hasil optimal dalam program produksi embrio adalah sapi donor yang berumur 3-4 tahun. Protein pakan yang diberikan sebesar $15 \%-20 \%$ telah sesuai dengan BSN (2009) yaitu pemberian sapi protein kasar pada sapi indukan minimal sebesar 14\%. Penggunaan kadar protein berbeda diharapkan dapat melihat produktivitas optimum dan menjaga kesehatan ternak. Menurut Kaslow (2010) peningkatan dan penurunan fraksi total protein di dalam tubuh berhubungan dengan status kesehatan.

\section{Perolehan Kualitas Embrio Tidak Layak Transfer (ETLT)}

Hasil perolehan ETLT dengan kadar protein pakan $16 \%$ menunjukkan rata-rata hasil yang tinggi. Perolehan kualitas embrio ETLT dari kedua bangsa berbeda dapat dilihat pada Tabel 3. Hal ini dimungkinkan perawatan sapi donor selama program superovulasi telah dilakukan dengan pemeliharaan dan manajemen yang baik terutama kesehatan individu sapi. Menurut Grimes (2008), adanya embrio tidak layak transfer dikarenakan kegagalan fertilisasi dan degenerasi embrio di dalam saluran reproduksi hewan donor. Banyaknya embrio yang tidak berkembang secara normal akan berpengaruh terhadap tingginya persentase embrio yang tidak layak transfer. Faktor yang dapat menyebabkan tingginya tingkat embrio yang tidak layak transfer adalah kondisi ovum, tingkat fertilisasi, dan perkembangan embrio yang terganggu (Riandi 2001). Penggunaan kadar protein diharapkan dapat mencegah terjadinya gangguan reproduksi sehingga dapat menurunkan tingkat embrio tidak layak transfer.

Menurut Anggorodi (1995) penambahan protein 
Tabel 3 Hasil perolehan Embrio Tidak Layak Transfer pada bangsa sapi dan kadar protein berbeda

\begin{tabular}{|c|c|c|c|c|c|c|}
\hline Bangsa & $\begin{array}{c}\text { Kadar protein } \\
(\%)\end{array}$ & $\begin{array}{l}\text { Jumlah ternak } \\
\text { (n) }\end{array}$ & $\begin{array}{l}\text { Total flushing } \\
\text { (unit) }\end{array}$ & $\begin{array}{l}\text { Total ETLT (flush- } \\
\text { ing }^{-1} \text { ekor }^{-1} \text { ) }\end{array}$ & $\begin{array}{l}\text { Rata-rata ETLT } \\
\text { (flushing }^{-1} \text { ekor }^{-1} \text { ) }\end{array}$ & $\begin{array}{c}\text { Kisaran ETLT } \\
\text { (flushing }{ }^{-1} \text { ekor }^{-1} \text { ) }\end{array}$ \\
\hline \multirow[t]{5}{*}{ Simmental } & 15 & 5 & 5 & 14 & $2,80 \pm 1,64$ & $1-5$ \\
\hline & 16 & 2 & 2 & 16 & $8,00 \pm 4,24$ & $5-11$ \\
\hline & 17 & 6 & 8 & 6 & $1,00 \pm 0,89$ & $0-2$ \\
\hline & 18 & 16 & 25 & 37 & $2,31 \pm 2,55$ & $0-8$ \\
\hline & 20 & 2 & 2 & 2 & $1,00 \pm 1,41$ & $0-2$ \\
\hline \multirow[t]{5}{*}{ Limousin } & 15 & 3 & 3 & 10 & $3,33 \pm 4,93$ & $0-9$ \\
\hline & 16 & 5 & 5 & 20 & $4,00 \pm 4,30$ & $0-9$ \\
\hline & 17 & 9 & 9 & 13 & $1,44 \pm 1,59$ & $0-4$ \\
\hline & 18 & 12 & 17 & 60 & $3,53 \pm 3,32$ & $0-11$ \\
\hline & 20 & 4 & 4 & 5 & $1,25 \pm 0,96$ & $0-2$ \\
\hline
\end{tabular}

Keterangan: (ETLT) embrio tidak layak transfer. Total ETLT merupakan jumlah embrio terkoleksi.

Tabel 4 Hasil perolehan UF pada bangsa sapi dan kadar protein berbeda

\begin{tabular}{|c|c|c|c|c|c|c|}
\hline Bangsa & $\begin{array}{c}\text { Kadar protein } \\
(\%)\end{array}$ & $\begin{array}{l}\text { Jumlah ternak } \\
\text { (n) }\end{array}$ & $\begin{array}{l}\text { Total flushing } \\
\text { (unit) }\end{array}$ & $\begin{array}{c}\text { Total UF } \\
\text { (flushing }^{-1} \text { ekor }^{-1} \text { ) }\end{array}$ & $\begin{array}{c}\text { Rata-rata UF } \\
\text { (flushing }^{-1} \text { ekor }^{-1} \text { ) }\end{array}$ & $\begin{array}{c}\text { Kisaran UF } \\
\text { (flushing }{ }^{-1} \text { ekor }^{-1} \text { ) }\end{array}$ \\
\hline \multirow[t]{5}{*}{ Simmental } & 15 & 5 & 5 & 27 & $5,40 \pm 2,41$ & $2-8$ \\
\hline & 16 & 2 & 2 & 17 & $8,50 \pm 3,54$ & $6-11$ \\
\hline & 17 & 6 & 8 & 7 & $1,17 \pm 0,41$ & $1-2$ \\
\hline & 18 & 16 & 25 & 81 & $5,06 \pm 10,75$ & $0-44$ \\
\hline & 20 & 2 & 2 & 4 & $2,00 \pm 1,41$ & $1-3$ \\
\hline \multirow[t]{5}{*}{ Limousin } & 15 & 3 & 3 & 16 & $5,33 \pm 3,79$ & $1-8$ \\
\hline & 16 & 5 & 5 & 23 & $4,60 \pm 6,62$ & $0-16$ \\
\hline & 17 & 9 & 9 & 43 & $4,78 \pm 7,03$ & $0-21$ \\
\hline & 18 & 12 & 17 & 67 & $3,94 \pm 5,33$ & $0-19$ \\
\hline & 20 & 4 & 4 & 4 & $1,00 \pm 0,82$ & $0-2$ \\
\hline
\end{tabular}

Keterangan: (UF) sel telur (ovum) yang tidak terbuahi. Total UF merupakan jumlah sel telur terkoleksi.

berperan memperbaiki jaringan tubuh, pertumbuhan jaringan baru, metabolisme energi, metabolism ke dalam za-zat vital dalam fungsi tubuh dan sebagai enzim essensial bagi tubuh. Kecernaan protein kasar dipengaruhi oleh tingginya kandungan protein kasar dalam ransum (Gracia et al. 1993).

Perolehan Sel Telur yang Tidak Terbuahi (UF)

Hasil perolehan tertinggi sel telur yang tidak terbuahi (UF) pada kadar protein pakan 16\%-15\%. Perolehan sel telur yang tidak terbuahi dari kedua bangsa berbeda dapat dilihat pada Tabel 4. Pengaruh pengaplikasian saat melakukan Inseminasi Buatan (IB) dan penentuan status reproduksi sapi donor yang kurang tepat sehingga menyebabkan tingginya perolehan sel telur yang tidak terbuahi UF. Hal tersebut dinyatakan Harsono (2001), waktu optimum untuk inseminasi buatan merupakan hal penting dikarenakan adanya birahi tenang (silent heat) dan lama estrus yang berbeda pada tiap individu sapi sehingga dapat menyebabkan waktu inseminasi kurang optimal yang menyebabkan rendahnya tingkat fertilitas yang diinginkan. Penggunaan semen yang berbeda pun menjadi pengaruh variasi UF yang tinggi karena masing-masing individu memiliki respon yang berbeda saat proses fertilisasi. Sumantri et al. (1997) menyatakan bahwa variasi individu sapi dan bangsa pejantan dapat menyebabkan terjadinya perbedaan dalam perkembangan embrio.

Menurut Duque et al. (2003) dan Kuran et al. (2002) faktor epigenetik memberikan peranan yang penting dalam perkembangan awal embrio, seperti ion, substrat energi, asam amino, vitamin, faktor pertumbuhan, sitokin, dan hormon. Selain itu, syarat sapi donor yang baik antara lain memiliki saluran reproduksi yang normal, sejarah post partum yang baik, dan memiliki siklus estrus yang teratur saat umur muda, serta tidak memiliki cacat genetik maupun cacat tubuh serta selalu mendapat kecukupan nutrisi pakan. Manajemen pemberian pakan berperan penting untuk produksi embrio karena, sapi dengan asupan energi berkurang memiliki folikel dominan berukuran lebih kecil dan siklus lebih dari 3 gelombang, dibandingkan dengan sapi dengan asupan pakan berkadar protein lebih tinggi, sehingga pengaruh nutrisi terhadap efisiensi reproduksi adalah pada tingkat produksi embrio (Boland et al. 2001).

Faktor genetik (sensitivitas respon variasi antara individu terhadap pemberian gonadotropin), karakteristik fisiologis (umur, kondisi ovarium, dan populasi folikel pada saat superovulasi), nutrisi, kesehatan organ reproduksi (ovarium, uterus, dan oviduct), dan jenis FSH komersial yang digunakan (Silva et al. 2009). Adapun faktor lain dalam 
variasi individu dalam merespon perlakuan superovulasi menurut OSU (2010), sapi donor harus dengan tingkat gizi yang sesuai karena sapi yang terlalu gemuk maupun terlalu kurus akan mengurangi tingkat kesuburan.

\section{KESIMPULAN}

Produktivitas embrio sapi yang dihasilkan dipengaruhi oleh beberapa faktor lingkungan sehingga perlu manajemen yang baik untuk dapat menanggulangi terjadinya penurunan produktivitas selama pemeliharan sapi. Pemberian pakan dengan kadar protein berbeda tidak memiliki pengaruh terhadap produksi embrio pada bangsa sapi simmental dan limousin. Faktor penting perolehan produksi kualitas embrio layak transfer tidak dipengaruhi oleh bangsa sapi yang berbeda.

\section{DAFTAR PUSTAKA}

Anggorodi R. 1995. Ilmu Makanan Ternak Umum. Jakarta (ID): PT Gramedia Pustaka.

[BSN] Badan Standarisasi Nasional. 2009. Standar Nasional Indonesia (SNI). SNI-02-3148-2009. Pakan Konsentrat Sapi Potong. Jakarta (ID): Dewan Standarisasi Indonesia.

Bearden HJ, Fuquay JW. 2000. Applied Animal Reproduction. Ed ke-5. New Jersey (US): Prentice Hall.

Boland MP, Lonergan P, O'Callaghan D. 2001. Effect of nutrition on endocrine parameters, ovarian physiology and oocyte and embryo development. Theriogenology 55: 1323-1340.

[DPKH] Direktorat Jendral Peternakan dan Kesehatan Hewan. 2015. Data Populasi dan Produksi Peternakan di Indonesia 2014-2015. Jakarta (ID): Departemen Pertanian.

Duque P, Gomez E, Diaz E, Facal N, Hidalgo C, Diez C. 2003. Use of two replacement of serum during bovine embryo culture in vitro. Theriogenology 59:889-899.

Gracia J, Galves F, De Blas JC. 1993. Effect substation of sugarbeet pulp of barley in diets for finishing rabbits on growth performance and on energy and nitrogen efficiency. J Anim Sci 71:1823-1830.

Grimes JF. 2008. Utilization of embryo transfer in beef cattle [internet]. [diunduh 2016 September 2]. Tersedia pada: http://ohioline.osu.edu.

Harsono R. 2001. Aplikasi komprehensif antara FSH dan PMSG untuk superovulasi pada ternak sapi potong dan perah [skripsi]. Bogor (ID): Institut Pertanian Bogor.

Kaneko JJ, Harvey JW, Bruss ML. 2008. Clinical Biochemistry of Domestic Animal. Ed ke-6. New York (US): Elsevier Inc.

Kaslow JE. 2010. Analysis of Serum Protein. Santa Ana (US): 720 North Tustin Avenue Suite 104.

Kuran M, Robinson JJ, Brown DS, McEvoy TG. 2002. Development amino acid utilization and cell allocation in bovine embryos after in vitro production in contrasting culture system. Reproduction in Domestic Animals 124:155-165.
McGeady TA, Quinn PJ, FitzPatrict ES, Ryan MT. 2006. Veterinary Embryology. Oxford (UK): Blackwell Publishing Ltd.

[OSU] Oklahoma State University (AS). 2010. Embryo Transfer in Cattle [internet]. [diunduh 2016 September 2]. Tersedia pada: http://osufacts.okstate.edu.

Puspita IKA. 2014. Evaluasi kualitas embrio hasil produksi embrio in vivo pada sapi dengan bangsa dan umur yang berbeda [skripsi]. Bogor (ID): Institut Pertanian Bogor.

Rensis FD, Scaramuzzi. 2003. Heat stress and seasonal effects on reproduction in the dairy cow a review. Theriogenology 60:1139-1151.

Riandi A. 2001. Kajian efektivitas dosis hormon follicle stimulating hormone (FSH) dalam metode superovulasi pada ternak sapi [skripsi]. Bogor (ID): Institut Pertanian Bogor.

Silva JCC, Alvarez RH, Zanenga CA, Pereira GT. 2009. Factors affecting embryo production in superovulated Nelore cattle. Reproduction in Domestic Animals 6:440-445.

Situmorang P, Triwulaningsih E. 2004. Aplikasi dan inovasi teknologi transfer embrio (TE) untuk pengembangan sapi potong. Lokakarya Nasional Sapi Potong 96-105. Bogor (ID): Puslitbang.

Sumantri C, Budiono A, Ooe M, Murakami M, Saha S, Suzuki T. 1997. Fertility of sperm from a tetraparental chimeric bull. Anim Reprod Sci 46:35-45.

Widiharih T. 2007. Buku Ajaran Perancangan Percobaan. Semarang (ID): Universitas Diponegoro. 